\title{
Development and Growth of Northern Leopard Frog, Lithobates pipiens, Tadpoles in North American Waterfowl Management Plan Permanent Basins and in Natural Wetlands
}

\author{
Daniel Pouliot and JeAn-JacQues Frenette
}

Département de Chimie-Biologie, Université du Québec à Trois-Rivières, 3351 Boulevard des Forges, C.P. 500, Trois-Rivières, Québec G9A 5H7 Canada

Pouliot, Daniel, and Jean-Jacques Frenette. 2010. Development and growth of Northern Leopard Frog, Lithobates pipiens, tadpoles in North American Watefowl Management Plan permanent basins and in natural wetlands. Canadian FieldNaturalist 124(2): 159-168.

We monitored the development and growth of a cohort of Northern Leopard Frog (Lithobates pipiens) tadpoles, in one North American Waterfowl Management Plan (NAWMP) permanent basin and in one natural environment, a bay of the St. Lawrence River. We wanted to know if this kind of artificial wetland could be considered as suitable habitat for this declining species and compare the environment that was provided to the tadpoles to those found in natural conditions. We also measured metamorphs' snout-vent length at three different permanent basins and natural bays to verify if the results from the detailed monitoring could be generalized. Our results have showed that the tadpoles were able to complete their development in the permanent basin and that their growth was superior to those from the natural site. The metamorphs from the permanent basins were also, on average, longer than those from the natural sites. The NAWMP permanent basins are suitable for the Northern Leopard Frog and could be a useful tool in the conservation of this species.

Nous avons suivi le développement et la croissance d'une cohorte de têtards de Grenouille Léopard du Nord (Lithobates pipiens) dans un bassin permanent du Plan Nord Américain de Gestion de la Sauvagine (PNAGS) et dans un site naturel, une baie du fleuve Saint-Laurent. Nous voulions vérifier si ce type d'aménagement pouvait être considéré comme un habitat potentiel pour cette espèce en déclin et comparer les conditions environnementales disponibles pour les têtards. Nous avons aussi mesuré la longueur museau-cloaque des métamorphes provenant de trois bassins permanents et de trois baies du SaintLaurent pour vérifier si les résultats obtenus par le suivi détaillé pouvaient être généralisés. Nos résultats ont montré que les têtards pouvaient compléter leur développement dans le bassin permanent et que leur croissance était aussi supérieure que dans le site naturel. Les métamorphes des trois bassins permanents étaient aussi, en moyenne, de taille supérieure à que ceux des sites naturels. Les bassins permanents du PNAGS peuvent être considérés comme des habitats potentiels pour la Grenouille Léopard du Nord. Ils pourraient représenter des outils utiles pour la conservation de cette espèce.

Key Words: Northern Leopard Frog, Grenouille léopard du Nord, Lithobates pipiens, tadpoles, têtards, North American Waterfowl Management Plan, Plan Nord Américain de Gestion de la Sauvagine, St. Lawrence River, Fleuve SaintLaurent.

The North American Waterfowl Management Plan (NAWMP) was signed by Canada and the United States in 1986 in response to the major waterfowl decline observed throughout North America; Mexico joined the continental plan in 1994 (NAWMP Plan Committee 1998*). The main goal of the plan is to return duck and goose populations to their 1970s levels (NAWMP Plan Committee 2004*). Habitat losses and wetland degradation over the last decades have greatly contributed to waterfowl decline (Batt et al. 1989). Among the solutions used by the NAWMP partners to achieve their goal, has been the establishment of a network of managed and/or protected wetlands across Canada, the United States, and Mexico. NAWMP partners have aimed to diversify the types of wetlands available in response to the specific needs of waterfowl (*D.U.C. and NOVE Environnement inc. 1990). Some of the managed wetlands are temporary; for example, land is flooded in early spring so that it can support migrating waterfowl, after which it is drained for agriculture at the beginning of the summer
(*Société de la Faune et Parcs Québec 2003). Other managed wetlands are permanent basins designed to provide waterfowl with sites for nesting and the raising of juveniles (D.U.C. and NOVE Environnement inc. $\left.1990^{*}\right)$.

Although NAWMP wetlands were developed for waterfowl, managers soon realized the potential of these managed areas for the conservation of other taxa. Managed wetland success stories have emphasized the quality of these wetlands for a diversity of birds (VanRees-Siewert and Dinsmore 1996; Locky et al. 2005) and for the growth of fish (e.g., Yellow-perch (Perca flavescens)) (Tardif et al. 2005). Schueler and Karstad (2000*) also note the abundance of the Northern Leopard Frog (Lithobates pipiens) in managed wetlands of the northern Ottawa River drainage in Ontario, Canada. They proposed that these wetlands may act as refuges or "source habitats" for this declining North American species in the Boreal Forest (Gibbs 1971; Wassersug 1976; Gilbert et al. 1994) and could contribute to the species survival at the local scale. 


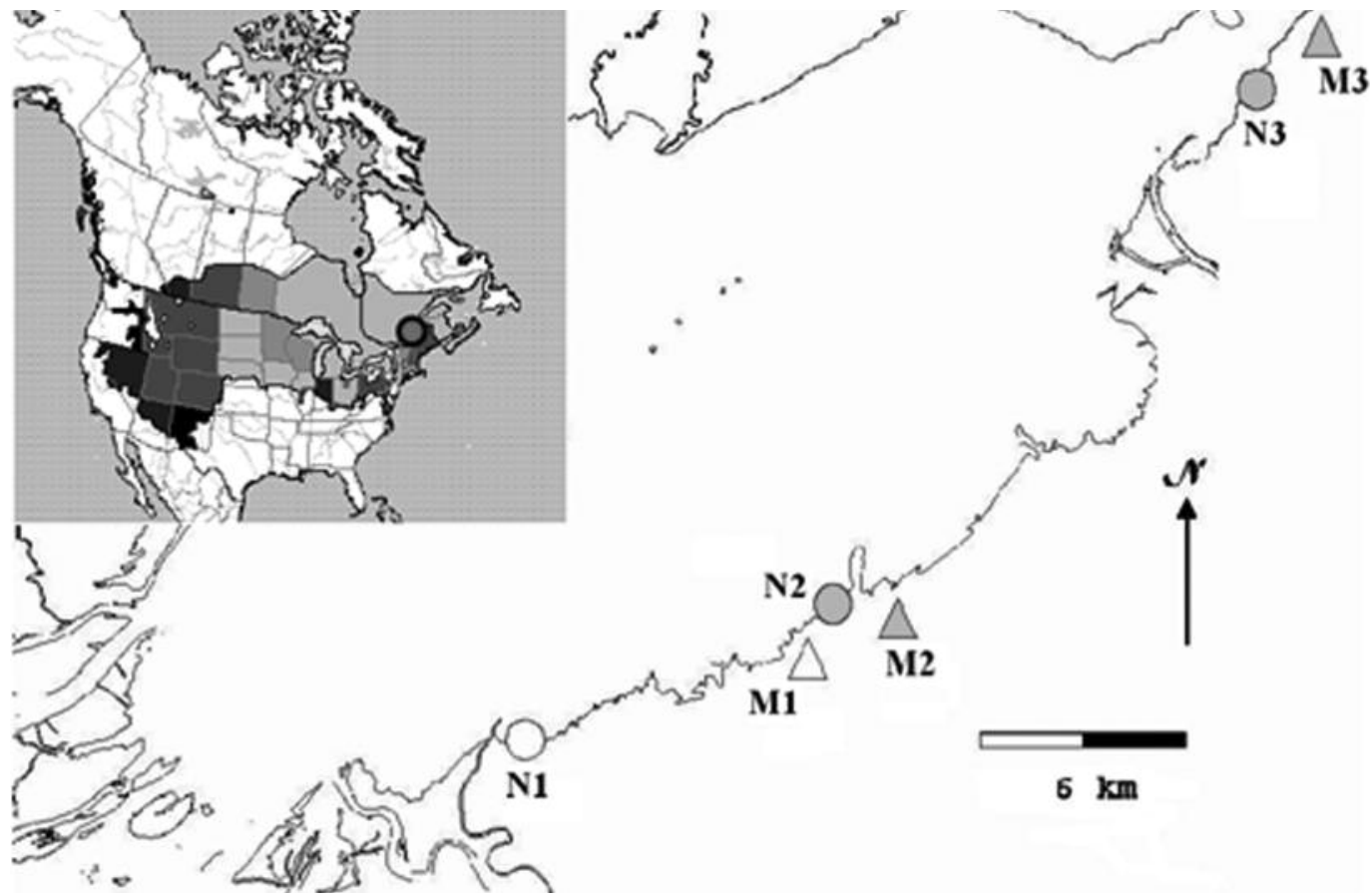

FIGURE 1. The circle on the top-left map shows the location of the study area. Northern Leopard Frog distribution is shown in tones of grey following the subnational "S" rank of NatureServe Conservation Status; the darker the tone the more endangered the species is (S5 to S1). The main image shows the locations of the study sites in Lac Saint-Pierre, St. Lawrence River, Canada: N1 and M1-Natural and Managed Monitoring Sites / N2, N3, M2 and M3-Natural and Managed metamorphosis sites.

The objective of the study reported here was to determine if the Northern Leopard Frog tadpole's were able to complete their development in one of these managed wetlands. We also wanted to compare it to the development and growth happening under natural environments and finally, explain the differences in tadpoles' development and growth by looking at the environmental conditions in their respective habitats.

\section{Methods}

Study sites

We conducted our research in Lac Saint-Pierre $\left(46^{\circ} 12^{\prime} \mathrm{N} ; 72^{\circ} 50^{\prime} \mathrm{W}\right)$, the largest fluvial lake $\left(480 \mathrm{~km}^{2}\right)$ along the St. Lawrence River in Quebec, Canada (Figure 1). Lac Saint-Pierre is characterized by its large floodplain $\left(180 \mathrm{~km}^{2}\right)$, which includes many natural and NAWMP-managed wetlands (Société de la Faune et Parcs Québec, 2003). The lake is shallow (mean depth of $3.17 \mathrm{~m}$ during the period of mean discharge) and covered with extensive macrophyte beds during most of the ice-free period.

\section{Natural sites}

The natural wetlands of Lac Saint-Pierre are colonized by plant communities that are sequentially drained from spring to summer. Water gradually uncovers first a Silver Maple (Acer saccharinum) forest, characterized by Reed Canarygrass (Phalaris arundinacea) in open areas, then, during the later stages, a low-depth marsh dominated by Common Spikerush (Eleocharis palustris) and various Bulrush species (Schoenoplectus fluviatilis, and $S$. acutus). Frogs lay their eggs in the flooded forest and tadpoles must follow the water mass, so their environmental conditions are dictated by the St. Lawrence River's water-level fluctuations.

North American Waterfowl Management Plan permanent basins

The NAWMP permanent managed wetlands in Lac Saint-Pierre are delimited by four dikes in a characteristic rectangular shape, a typical arrangement for this type of wetland (Figure 2). Water accumulates following snowmelt and spring rains. Water levels decrease gradually over the summer by evaporation and transpiration, but a pumping station can be activated to add water from the St. Lawrence River if the wetland becomes too dry. Drainage channels are present but the wetland is not usually flushed. The wetlands exhibit a depth gradient that allows for the establishment of mainly three aquatic plant communities: (1) the shallow water is dominated by an arborescent swamp of willow (Salix spp.) and/or Ash (Fraxinus spp.), with 


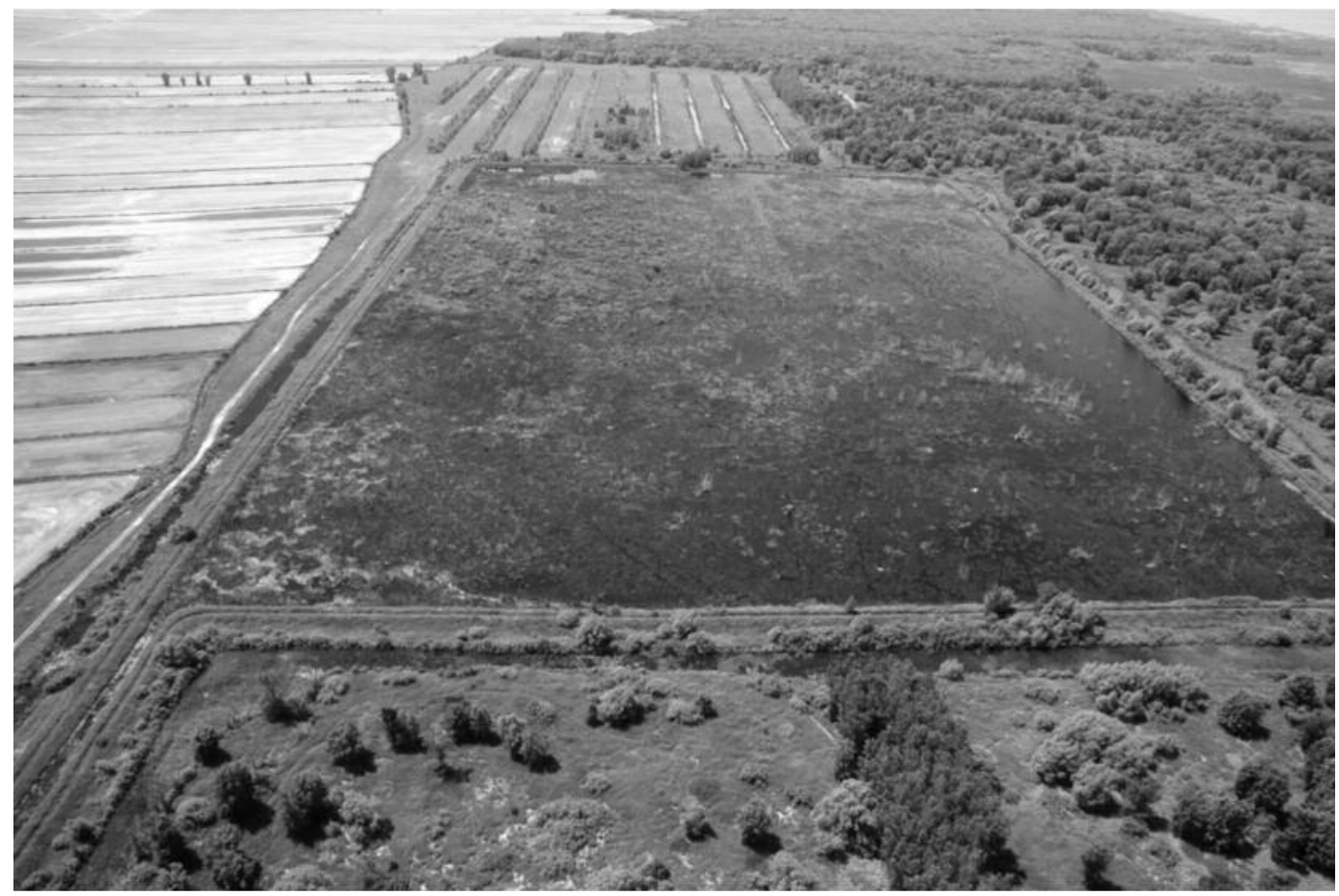

FIGURE 2. The NAWMP permanent basin where tadpole' environment, development, and growth have been monitored. It exhibits the typical rectangular shape of a this artificial wetland design. Photo by André Michaud (Ducks Unlimited Canada). Used with permission.

dense aggregations of Cattail (Typha angustifolia); (2) the open marsh is densely colonized by common Spikerush, an invasive flowering rush (Butomus umbellatus) at middle depths; and (3) open water is covered with submerged vegetation in the deepest areas. Northern Leopard Frog eggs are laid in both the arborescent swamp and the open marsh.

We characterized Northern Leopard Frog tadpole development, growth and immediate environment, at weekly intervals, in one natural site (N1) and in one NAWMP permanent basin (M1) during the 2004 season (Figure 1). These sites will henceforth be referred to as natural and managed monitoring sites. The monitoring began with the first observation of egg masses (14 May; designated week 1) and ended ten weeks later with the beginning of metamorphosis (13 July; designated week 10). We caught and measured metamorphs (Gosner stage 46) in our two monitoring sites (N1 and M1), as well as in four other sites (Figure 1), (further referred to as natural and managed metamorphosis sites). These four sites included two natural bays (N2 and N3), and two NAWMP permanent basins (M2 and M3). We also used SVL data from the same sites, both monitoring and metamorphosis, obtained by D. P., during previous works in 2003 and 2005.

\section{Localization of Tadpole Habitat}

Wetlands are highly heterogeneous ecosystems and tadpoles do not necessarily use all available areas. To ensure that we characterized the environmental conditions in areas only occupied by tadpoles, we first localized the tadpole habitats. To do so, we measured tadpole density with a dip net passed twice through the water column (following the bottom, horizontally, for about meter). The volume of water that passed through the net varied with water depth, from 0.08 to $0.13 \mathrm{~m}^{3}$. We expressed tadpole density per unit of water volume (tadpoles $\left./ \mathrm{m}^{3}\right)$.

In each of our two monitoring sites, every week, we measured tadpole density at 30 locations that were selected randomly and separated by a minimum of 20 meters. We considered representative tadpole habitat to be: the three locations in each of the natural and the managed wetlands with the highest density of Northern Leopard Frog tadpoles.

\section{Environmental Conditions}

In each of the three tadpole habitats, at both natural and managed monitoring sites, as selected weekly between $09 \mathrm{~h} 00$ and $15 \mathrm{~h} 00$, we measured the water depth using a meter stick $(0.5 \mathrm{~cm}$ increments) and the surface water temperature with a thermometer $\left(0.5^{\circ} \mathrm{C}\right.$ 
increments). We measured, in situ, photosynthetically active radiation (PAR) with a light meter (Li-COR $\mu \mathrm{moles} / \mathrm{m}^{2} / \mathrm{sec}$ ) and calculated the extinction coefficient $\left(K_{d}\right.$ PAR) following Wetzel and Likens (1991). We collected four liters of water in $2 \mathrm{~L}$ polypropylene containers. We pre-filtered the water samples on $63 \mu \mathrm{m}$ Nitex (Filmar inc.) to eliminate large zooplankton and minimize grazing on the algae/protist community during the shipment of the water to the lab. Prefiltered water samples were kept in a cooler with ice packs until arrival at the lab, where they were rapidly transferred to a dark room maintained at $4^{\circ} \mathrm{C}$.

We used a $200 \mathrm{~mL}$ subsample to analyze for total nitrogen (TN) and total phosphorus (TP) according to standard methods in use in Yves Prairie's laboratory (GRIL). For sestonic chlorophyll $a(\mathrm{Chl} a$ ) determination, we filtered water samples the same day on a duplicate GF/F filter $(0.7 \mu \mathrm{m})$; extraction was by hot ethanol following Nusch (1980). Sestonic organic matter dry weight was measured according to Wetzel and Likens (1991). We used these variables to characterize the food availability in the water column. Chl $a$ represents a measure of phytoplankton biomass. The sestonic organic matter dry weight includes living organisms and decaying matter such as feces, which are known to be beneficial for tadpole development and growth (Steinwascher 1978).

We used epiphytic periphyton attached to dominant macrophyte species as another index of food availability for tadpoles; at each tadpole representative habitat, we collected ten grams of submerged parts from the most representative macrophytes in a plastic bag containing $100 \mathrm{~mL}$ of distilled water. We agitated the bag for two minutes to thoroughly separate epiphytic periphyton from the macrophyte substrate. We then cleaned the macrophytes with a known volume of distilled water. The result of the washing-agitation process was a volume-known homogenate of distilled water and epiphytic algae/protists. We filtered this homogenate the same day on $\mathrm{GF} / \mathrm{F}$ filter $(0.7 \mu \mathrm{m})$ to evaluate the epiphytic Chl $a$ biomass and epiphytic organic matter dry weight. We expressed epiphyte Chl $a$ and organic matter availability per unit of plant area that we measured using an area-meter (AMC100 ADC Bioscientific LTD). Finally, to obtain a more realistic idea of the amount of available epiphytic food resources (Chl $a$ and organic matter), we calculated the following epiphytic food availability index (EFA index) for each station: site/week but the final number between site and week is more variable. At first, tadpoles were identified by their uniformly black beak and later by the pattern of their back. Tadpoles were brought to the lab in a cooler with ice packs, euthanized using MS-222 and preserved in $10 \%$ neutral buffered formalin according to McDiarmid and Altig (1999). We determined developmental stage for all preserved tadpoles according to Gosner (1960). Tadpoles were individually, and briefly, placed on a dry towel to absorb excess fluid and weighed to the nearest $0.05 \mathrm{mg}$ using a Sartorius balance (model CP225D).

\section{Metamorphs}

In 2004, during the week following the beginning of metamorphosis, we evaluated the length of the metamorphs (Gosner stages 46) at all six sites (monitoring $\mathrm{N} 1$ and M1 and metamorphosis N2, N3 and M2, M3). We caught metamorphs at the water-land interface, using a dipnet. We attempted to catch as many metamorphs as possible, during a period of approximately two hours per site. We measured the snout-vent length (SVL) with a caliper (Mitutoyo), marked every individual by cutting a single toe and releasing them on catch location.

Metamorphs SVL from previous years had been collected through the same methodology, at site M1, $\mathrm{N} 1$ and N2, in 2003 and 2005. We integrated this data to verify if the difference in the size at metamorphosis observed in 2004 was also present for other years.

\section{Statistical Analyses}

All statistical analyses were performed with SYSTAT 11. A discriminant function was obtained following a stepwise DFA ( $F$ to enter or reject 0.15 ) on the environmental variables. We used this analysis to identify variables or groups of variables that could best differentiate the characterized monitoring sites. Most variables were log or square root transformed to attain a normal distribution before DFA was performed. We used a two-tailed $t$-test to determine whether there was a significant difference $(\alpha=0.05)$ between the mean length of metamorphs from the natural and managed sites (N1, N2, N3 vs. M1, M2, M3).

\section{Results \\ Environmental Conditions}

Sestonic Chl $a$, maximum tadpole density, $\mathrm{K}_{\mathrm{d}}$ PAR, and the ratio of TN:TP were entered into a discriminant function that correctly classified the natural and

\section{EFA index $=\underline{\text { ug Chl } a / \mathrm{cm}^{2}} \underline{\text { or }} \underline{\underline{\operatorname{mg}} \text { Organic matter } / \mathrm{cm}^{2}} *$ Macrophyte $\%$ cover $*$ Water depth}

\section{Tadpole Development and Growth}

We monitored tadpole development and growth based on weekly captures in the six representative tadpole habitats, divided among the natural and managed monitoring wetlands. Our objective was to catch a minimum of 15 Northern leopard frog tadpoles per managed representative habitats in 74 to $79 \%$ of cases (Table 1). This discriminant function explained $46 \%$ of the total variance. Plotting of stations' discriminant function scores over time show that tadpole environments in the managed wetland were characterized by 
TABLE 1. Results of the discriminant function analysis. The multivariate analysis indicates a significant difference between the two groups of Northern Leopard Frog tadpole habitats (Wilks' lambda $=0.684$, Pillai Trace $=0.316$, Lawley-Hotelling trace $=0.462 ; \mathrm{df}=4, F$-ratio $=6.008, P=0.0006$ ); eigenvalue $=0.462$.

\begin{tabular}{|c|c|c|c|c|}
\hline Variables & $\begin{array}{c}\text { Canonical } \\
\text { discriminant functions }\end{array}$ & $F$-to-remove & Tolerance & $\begin{array}{c}\text { CDF standardized } \\
\text { by within variances }\end{array}$ \\
\hline Constant & 10.472 & & · & . \\
\hline TN:TP & 2.411 & 13.31 & 0.823 & 0.885 \\
\hline Sestonic Chl $a$ & 0.846 & 9.82 & 0.760 & 0.813 \\
\hline Tadpole density & -0.250 & 3.21 & 0.966 & -0.436 \\
\hline $\mathrm{K}_{\mathrm{d}}$ PAR & -0.381 & 0.93 & 0.873 & -0.252 \\
\hline Classification matrix & Natural & Managed & $\%$ Correct & \\
\hline Natural & 23 & 7 & 77 & \\
\hline Managed & 5 & 22 & 81 & \\
\hline Total & 29 & 28 & 79 & \\
\hline Jackknifed & Natural & Managed & $\%$ Correct & \\
\hline Natural & 22 & 8 & 73 & \\
\hline Managed & 7 & 20 & 74 & \\
\hline Total & 28 & 29 & 74 & \\
\hline
\end{tabular}

higher TN:TP ratios, higher sestonic Chl $a$ availability, lower maximum tadpole density, and lower light extinction coefficients than the tadpoles from the natural monitoring site (Figure 3). Water depth, water temperature, sestonic organic matter, and periphytic food availability were not retained in the discriminant function, and are therefore considered to be relatively similar over time in both sites.

\section{Development and Growth}

Table 2 is showing the number of tadpoles caught, measured and weight, in each of the two monitoring sites in 2004. Figure 4 shows tadpole development (Gosner stage) at the two monitoring sites. The development generally followed the same pattern at both sites. However, from week 6 to 10 (15 June to 13 July), the variation in Gosner stages were greater in the natural wetland than the managed one, suggesting that a greater proportion of the tadpoles were not ready for emergence in the natural monitoring wetland compare to the more homogenous readiness in the managed monitoring site.

Because Gosner stages are highly correlated with time (Pearson correlation coefficient $r_{\mathrm{p}}=0.941$ ), wet weight of tadpoles were plotted against Gosner stages (Figure 5). This allowed comparison of individual tadpole weights for a given Gosner stage. Our results indicate similar growth patterns during the first three to four weeks in both monitoring sites. Afterward that time period, between weeks 5 and 9 (8 June to 8 July), tadpoles from the managed wetland grew more rapidly than those in the natural site (Figure 5).

The weight loss observed during week 9 (8 July) in the natural wetland and in week 10 (13 July) in the managed wetland, corresponds to the beginning of metamorphosis in each habitat (Gosner stage $\geq 42$ ). At maximum mean wet weight, just before the begin-
TABLE 2. Sample size (number of tadpoles caught, killed, staged and weighted) per week, in the two monitoring sites, in 2004.

\begin{tabular}{|c|c|c|c|}
\hline Week & Date & $\begin{array}{c}\text { Monitoring } \\
\text { site }\end{array}$ & $\begin{array}{c}\text { Sample size } \\
\text { (tadpoles) }\end{array}$ \\
\hline \multirow[t]{2}{*}{1} & \multirow[t]{2}{*}{ May 14} & Natural & 68 \\
\hline & & Managed & 41 \\
\hline \multirow[t]{2}{*}{2} & \multirow[t]{2}{*}{ May 18} & Natural & 90 \\
\hline & & Managed & 46 \\
\hline \multirow[t]{2}{*}{3} & \multirow[t]{2}{*}{ May 25} & Natural & 50 \\
\hline & & Managed & 32 \\
\hline \multirow[t]{2}{*}{4} & \multirow[t]{2}{*}{ June 02} & Natural & 41 \\
\hline & & Managed & 26 \\
\hline \multirow[t]{2}{*}{5} & \multirow[t]{2}{*}{ June 08} & Natural & 54 \\
\hline & & Managed & 24 \\
\hline \multirow[t]{2}{*}{6} & \multirow{2}{*}{ June 15} & Natural & 40 \\
\hline & & Managed & 15 \\
\hline \multirow[t]{2}{*}{7} & \multirow[t]{2}{*}{ June 22} & Natural & 43 \\
\hline & & Managed & 7 \\
\hline \multirow[t]{2}{*}{8} & \multirow[t]{2}{*}{ June 29} & Natural & 56 \\
\hline & & Managed & 18 \\
\hline \multirow[t]{2}{*}{9} & \multirow[t]{2}{*}{ July 08} & Natural & 43 \\
\hline & & Managed & 12 \\
\hline \multirow[t]{4}{*}{10} & \multirow[t]{2}{*}{ July 13} & Natural & 44 \\
\hline & & Managed & 12 \\
\hline & \multirow{2}{*}{ TOTAL } & Natural & 529 \\
\hline & & Managed & 233 \\
\hline
\end{tabular}

ning of metamorphosis, tadpoles from the managed wetland were more than three times as heavy as those from the natural wetland.

\section{Metamorphs}

Metamorphs from the managed monitoring site $($ Mean $=4.953 \mathrm{~g}($ SD 0.882); Range $=3.0-7.5 ; n=89)$

(Table 3) were significantly heavier $(P<0.001 ; t=$ 35.132 ; df $=188$ ) than those from the natural moni- 


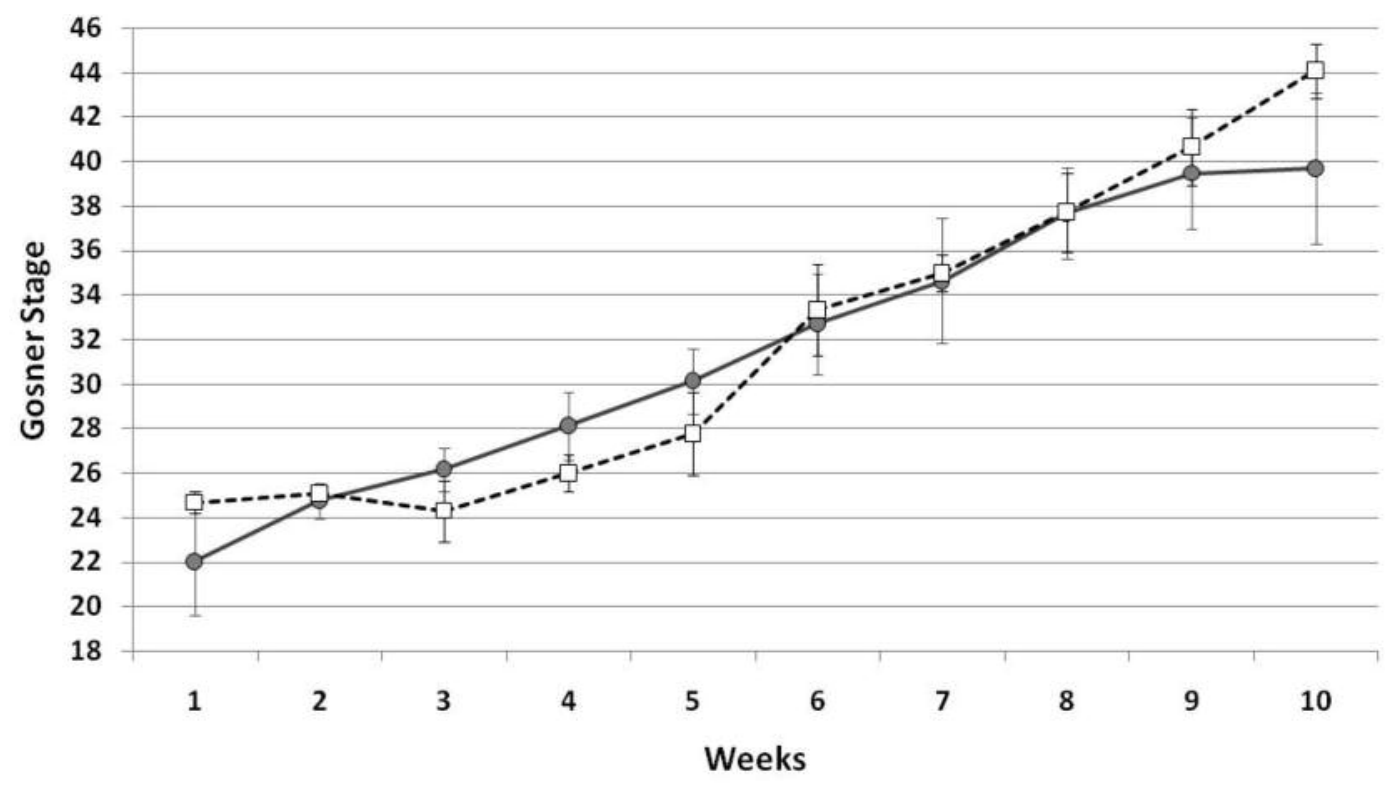

FIGURE 3. Weekly average (SD) tadpole Gosner stages, from week 1 to 10 (May $14^{\text {th }}$ to July $13^{\text {th }} 2004$ ), in the two monitoring sites: natural wetland ( $\bigcirc$ and solid line) and the NAWMP permanent basin ( $\square$ and broken line).

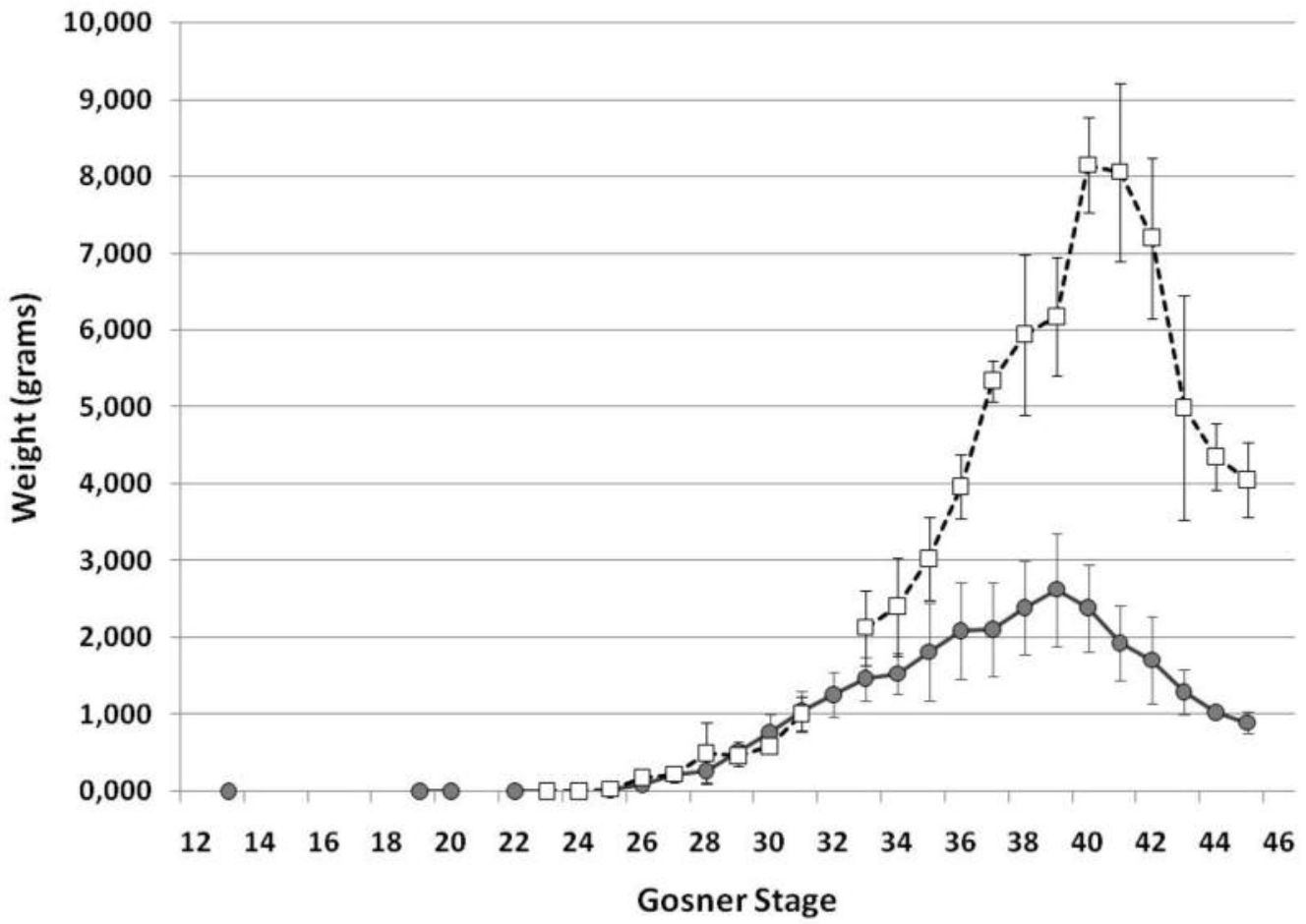

FIGURE 4. Average (SD) tadpole weight in grams, in function of the Gosner developmental stage, in the two monitoring sites: natural wetland ( $\bigcirc$ and solid line) and the NAWMP permanent basin ( $\square$ and broken line). 


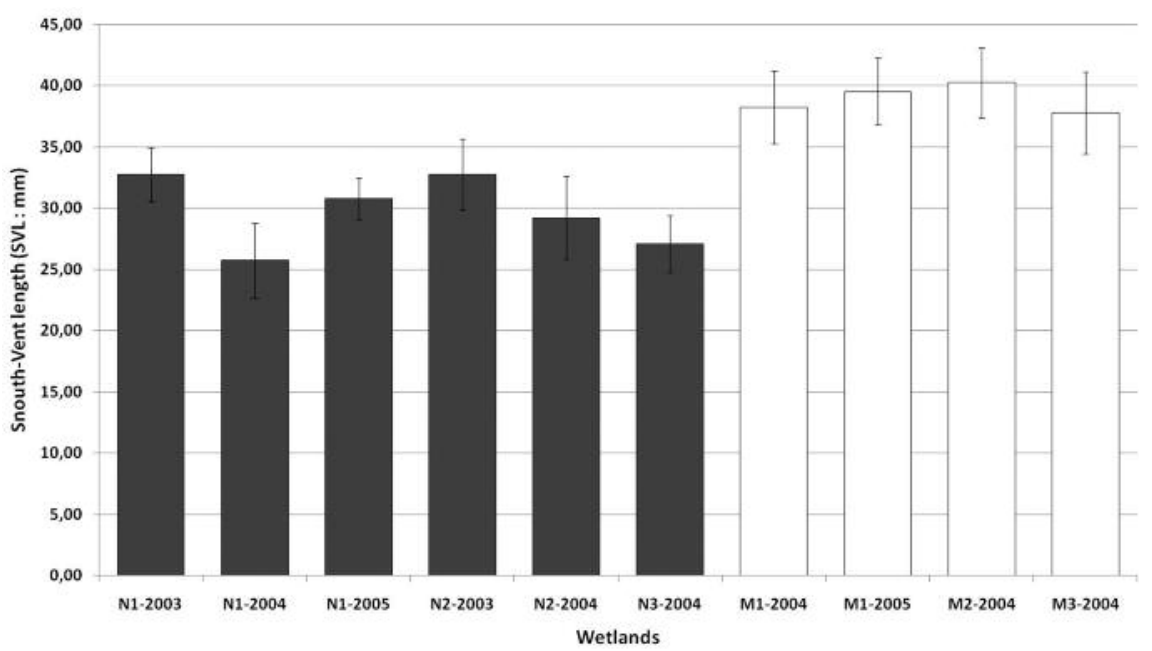

FIGURE 5. Snout-vent length of metamorphs from three natural bays (grey bars) and three permanent managed wetlands (white bars) on the south shore of Lac Saint-Pierre from 2003 to 2005. See Figure 1 for collection sites.

toring site $($ Mean $=1.471 \mathrm{~g}(\mathrm{SD} 0.454)$; Range $=0.5-$ $3.0 ; n=106)$. The two-tailed $t$-test performed on the of metamorphs' SVL from the six metamorphosis sites, showed that metamorphs from the managed wetland were significantly longer $(P<0.001 ; t=26.995 ; \mathrm{df}=$ 398) than those from the natural wetland (Figure 6).

\section{Discussion \\ NAWMP Permanent Basin as suitable habitat for Northern Leopard Frog tadpoles?}

Our first objective was to determine if Northern Leopard Frog eggs laid in a NAWMP permanent basin could complete development. The monitoring of the development during the spring and summer 2004 in one of such basins, and the metamorphosis of froglets in mid-July 2004 in three different basins, strongly suggests that NAWMP permanent basins can be considered suitable habitat for Northern Leopard Frog tadpoles. Moreover, the previous observation of metamorphs in some of these basins in 2003 and 2005 supports the idea that the basins are not only sporadically suitable, but likely annually so.

In comparison to other NAWMP managed wetlands, the permanent basin presents the advantage that the minimum water level is maintained throughout the season. Such management practices eliminate the possibility of a lethal drying event. Such lethal events occur in other types of managed wetlands (Pouliot and Frenette, personal observation); temporarily flooded managed wetlands, designed as migratory stops for waterfowl, cannot support tadpoles up to metamorphosis since they are drained in early summer. Smaller artificial ponds connected to the St. Lawrence are sen-
TABLE 3. Sample size (number of metamorphs caught, marked and snout-vent length measured, during the week following the observation of the first metamorphosis signs, in the six metamorphosis sites, in 2003, 2004 and 2005, depending on data availability.

\begin{tabular}{lccc}
\hline \hline Wetland & Year & $\begin{array}{c}\text { Metamorphosis } \\
\text { site }\end{array}$ & $\begin{array}{c}\text { Sample size } \\
\text { (metamorphs) }\end{array}$ \\
\hline Natural & 2003 & N1 & 35 \\
Natural & 2004 & N1 & 105 \\
Natural & 2005 & N1 & 31 \\
Natural & 2003 & N2 & 35 \\
Natural & 2004 & N2 & 12 \\
Natural & 2004 & N3 & 31 \\
Managed & 2004 & M1 & 85 \\
Managed & 2005 & M1 & 19 \\
Managed & 2004 & M2 & 45 \\
Managed & 2004 & M3 & 2 \\
\hline \hline
\end{tabular}

sitive to the variation of the river's water level and can dry out over the summer, or are used by warm water fish such as Brown Bullhead (Ameiurus nebulosus), Northern Pike (Esox lucius) and Smallmouth Bass (Micropterus dolomieui), all of which are potential predators for the tadpoles.

Tadpoles that developed in the NAWMP permanent basins grew more rapidly and emerged at a larger size than those from the natural sites. Size at metamorphosis is known to be important in amphibian life history (Wilbur and Collins 1973; Smith, 1987) as it affects individual survival (Altwegg and Reyer 2003) and the reproductive potential of adults (Smith 1987; Semlitsch et al. 1988). Considering the significance of 


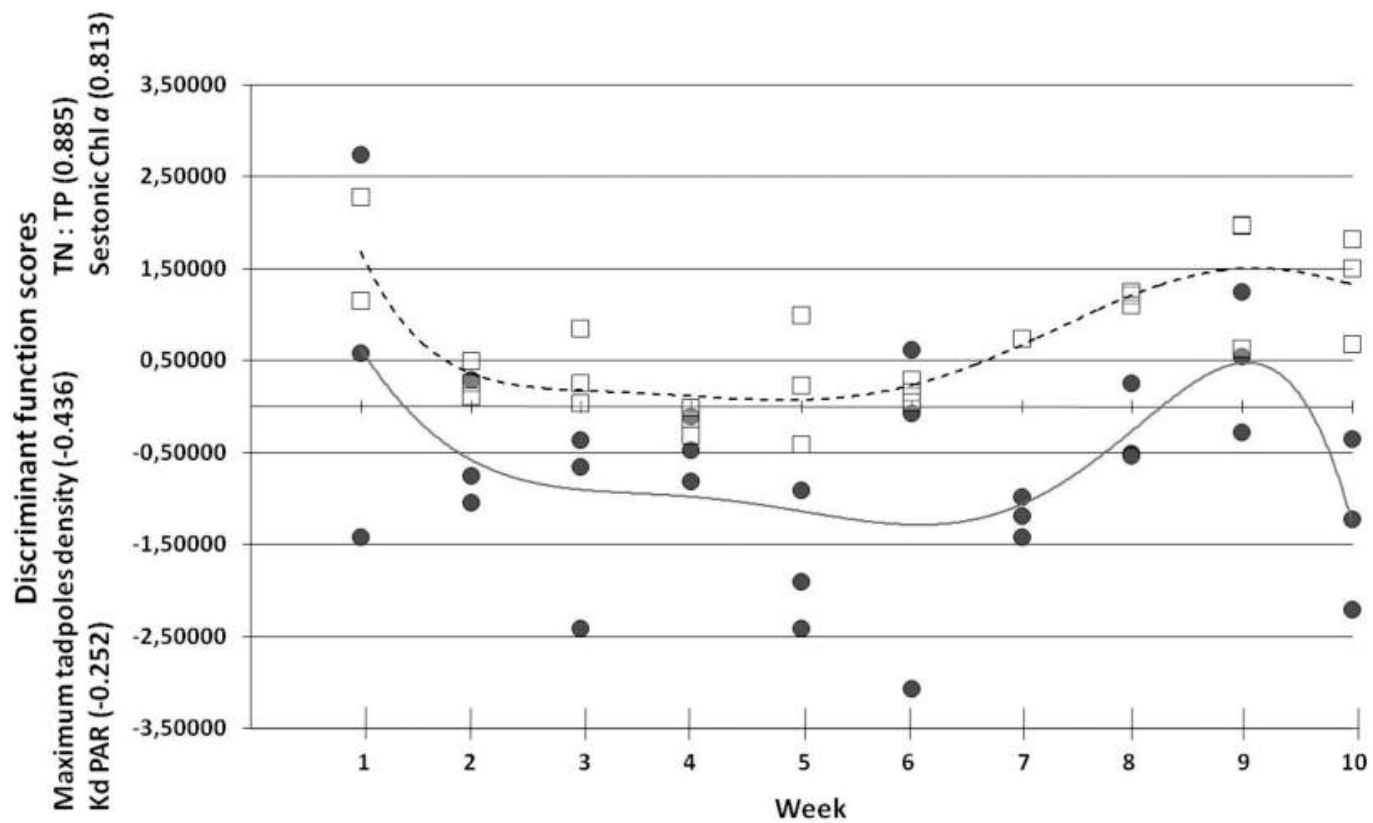

FIGURE 6. Weekly discriminant function scores, from May 14th to July 13th 2004, for tadpole habitat in the natural wetland ( $\bigcirc$ and solid line) and the NAWMP permanent basin ( $\square$ and broken line). Polynomial curves used to show trend over the development period.

size at metamorphosis in amphibian life history, metamorphs produced by the permanent basins have equal, or maybe even higher chances to survive, than those produced by the natural wetlands. This emphasizes the capacity of NAWMP permanent basin to be a suitable habitat.

Considering that the Northern Leopard Frog tadpoles which evolved in the permanent basins completed their development and demonstrated a superior growth rate than those from the natural sites, the NAWMP permanent basins seem to be an interesting and promising tool for the local conservation of the Leopard Frog. The success of the different headstarting programs could potentially be increased by focusing the reintroduction efforts in areas where NAWMP permanent basins are present. By offering suitable development habitat, the permanent basins could lead to the establishment of self-sustaining populations. Further research should investigate whether the success story reported here is repeated in regions where the species is at risk, since different results could be expected in others regions.

\section{Relationship between environmental conditions and} tadpole development and growth

Our second objective was to describe and compare the environment of the tadpoles in our two wetlands to better understand the success or failure of the NAWMP permanent basin in supporting Northern Leopard Frog tadpoles throughout their development. The following variables: (1) TN:TP ratios; (2) $\mathrm{K}_{\mathrm{d}}$ PAR coefficients; (3) sestonic Chl $a$; and (4) maximum tadpole density, were grouped together in a discriminant function that associated tadpole habitat stations to the correct wetland (natural or artificial) in $74-79 \%$ of cases. This function explained $46 \%$ of the total variance.

$\mathrm{TN}$ :TP ratio and $\mathrm{K}_{\mathrm{d}}$ PAR are known to influence phytoplankton/periphyton community structure (Smith, 1986; Scheffer et al. 1997). The algae and protists that compose such communities - such as diatoms, dinoflagellates, chlorophytes, and cyanobacteria-are known to be of unequal food quality for tadpoles. Diatoms are generally considered high-quality food (Bold and Wynne 1985; Huggins et al. 2004) and cyanobacteria low-quality food (Brett and Muller-Navara 1997). Combined with a high $\mathrm{K}_{\mathrm{d}}$ PAR coefficient (low light penetration), a low $(<29)$ TN:TP ratio favours cyanobacteria dominance in the phytoplanktonic community, with a consequent decrease in food quality for consumers (Smith 1986; Scheffer et al. 1997). Tadpoles raised in environments of higher quality food grow more quickly and metamorphose at greater size (Kupferberg 1997). Despite the fact that both wetlands had mean TN:TP ratios lower than 29 , the ratios at the natural wetland were always lower than those at the managed site. Moreover, the natural wetland usually presented a higher light extinction coefficient, meaning that less light is penetrating the water column, favoring 
the lower quality cyanobacteria over the better quality diatoms and chlorophytes. Considering these characteristics of the natural wetland, we suggest that the available food resources were of lower quality, which could have contributed to the differences in growth and size at metamorphosis. Further investigations should consider direct algae counts to establish phytoplankton/ periphyton community structure and test this hypothesis.

Murray (1990) and Johnson (1991) observed that tadpoles that developed in food-rich environments grew more and metamorphosed at bigger sizes. It is also generally accepted that high tadpole density results in slower growth rates and smaller sizes at metamorphosis (Gromko et al. 1973; John and Fenster 1975; Wilbur 1977; Smith 1983). This has been explained by competition for available food resources (Wilbur 1977b; Berven and Chadra 1988; Murray 1990; Johnson 1991) and by higher frequencies of physical contacts between tadpoles, which is associated with reduced feeding time and growth (Gromko et al. 1973; John and Fenster 1975). Our results are consistent with these studies, since smaller sizes at metamorphosis were observed in the natural site, where lower quantities of food and higher maximal densities of tadpoles were observed.

Higher density also results in a greater range between lower and higher Gosner stages in a given cohort, since bigger tadpoles express competitive dominant behavior over smaller ones (Wilbur and Collins 1973). Our results suggest such competition due to higher densities. A larger range in Gosner stages was observed in the natural site, mainly when tadpole density was generally increasing, however this remained constant in the managed one.

Another potential explanation that may not have been captured by our monitoring is the aquatic connectivity of habitat areas. The higher the water level, the greater the connectivity; therefore the area of available habitat for aquatic organisms is also increased. In the context of high connectivity, tadpoles can disperse and forage in lower densities, feeding efficiently on available food resources. This scenario prevailed during the first weeks of development at both sites. It was essentially during this time, between weeks three and six that tadpoles at the natural site grew. When connectivity is low, available habitat becomes limited and tadpoles are forced to aggregate in remnant pools. This drastic change in tadpole habitat at the natural wetland is generated by the falling water level of the Saint-Lawrence River, concentrating tadpoles and their food in small pools (Figure 7).

These new environmental conditions should curtail tadpole growth for the reasons previously discussed. All these stressful conditions should favour the augmentation of development rate over growth in order to escape poor conditions. This ultimately results in smaller metamorphs, as proposed by Wilbur and Collins (1973).

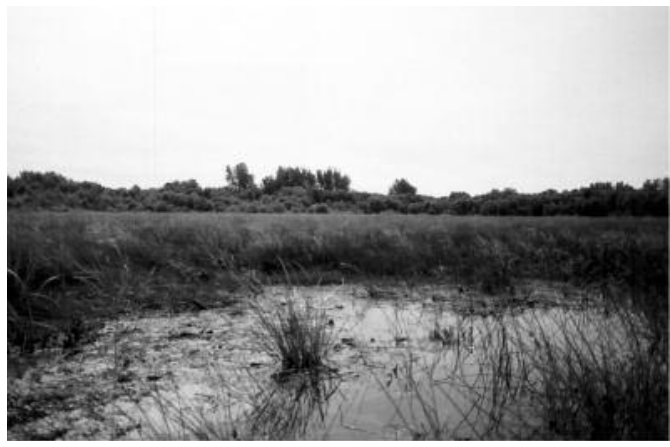

FIGURE 7. Natural monitoring site on Week 9 (8 July 2004). During the summer, the water level decreases in the St. Lawrence River to the point that Northern Leopard Frog tadpoles are constrained to small pools, like the one shown here. Photo by Daniel Pouliot.

Again, in the theoretical perspective that the aquatic connectivity is the proxy for the Northern Leopard Frog development success and metamorphosis size, along the St. Lawrence and its floodplain, the local presence of the NAWMP permanent basins could definitively contribute to the maintenance of the species in the region. Since the St. Lawrence River water level has shown great inter-annual variation over the last decades (Hudon 1997), we could expect Northern Leopard Frog populations to also experience a great inter-annual variation in the recruitment rate in natural sites. On the other hand, the relatively stable water level conditions of the NAWMP permanent basins could be providing an annually equivalent flow of young Northern Leopard Froglets to the local populations.

\section{Acknowledgments}

We are grateful to J.-F. Lapierre, M. Lefebvre, D. Deshaies, and P. Lavallé for their able help with data collection. Thanks to J.-F. Desroches, F. W. Schueler, Marla Bojarski, and two anonymous reviewers, for their useful comments on the preliminary version of the text. Thanks to the Ministère des Ressources naturelles et de la faune du Québec for providing research permit (\# 2004-06-21-028-17-SP). This research was funded by a) a grant from the Natural Sciences Research Council of Canada (NSERC) and the Fonds Québécois de la Recherche sur la Nature et les technologies (FQRNT) to J.-J. Frenette and b) a FQRNT postgraduate fellowship to D. Pouliot. This study is a contribution of the Groupe de Recherche Interuniversitaire en Limnologie (GRIL).

\section{Documents Cited (marked * in text)}

D.U.C. [Ducks Unlimited Canada], and NOVE environnement inc. 1990. Projet d'aménagement de la Commune de la Baie-du-Febvre. Étude d'impact sur l'environnement déposée au près du Ministère de l'Environnement du Québec. 134 pages. 
NAWMP [North American Waterfowl Management Plan, Plan Committee]. 1998. North American Waterfowl Management Plan 1998. Strategic guidance: expanding the vision. Canadian Wildlife Service, U.S. Fish and Wildlife Service, Secretaria de Medio Ambiente y Recursos Naturales. 32 pages.

NAWMP [North American Waterfowl Management Plan, Plan Committee]. 2004. North American Waterfowl Management Plan 2004. Strategic guidance: strengthening the biological foundation. Canadian Wildlife Service, U.S. Fish and Wildlife Service, Secretaria de Medio Ambiente y Recursos Naturales. 22 pages.

Schueler, F. W., and A. Karstad. 2000. Northern Ontario Ducks Unlimited marshes: refugia for leopard frogs? Proceeding of the 5th Canadian amphibian and reptile conservation network annual meeting.

Société de la Faune et des Parcs du Québec. 2003. Le lac Saint-Pierre: Portrait des aménagements et autres sites d'intérêt faunique. Direction de l'aménagement de la faune Mauricie - Centre-du-Québec, Trois-Rivières, Canada. 176 pages.

\section{Literature Cited}

Altwegg, R., and H. U. Reyer. 2003. Patterns of natural selection on size at metamorphosis in water frogs. Evolution 57: 872-882.

Batt, B. D. J., M. G. Anderson, C. D. Anderson, and F. D. Caswell. 1989. The use of prairie potholes by North American ducks. Pages 204-227 in Northern Prairie Wetlands. Edited by A. G. Van Der Valk. Iowa State University Press, Ames, Iowa, USA.

Berven, K. A., and B. G. Chadra. 1988. The relationship among egg size, density and food level on larval development in the wood frog (Rana sylvatica). Oecologia 75: 6772.

Bold, H. C., and M. J. Wynne. 1985. Introduction to the Algae: Structure and Reproduction, second edition. Prentice-Hall, Inc., Englewood Cliffs, New Jersey, USA.

Brett, M. T., and D. C. Muller-Navara. 1997. The role of essential fatty acids in aquatic food web processes. Freshwater Biology 38: 483-499.

Gibbs, E. L., G. W. Nace, and M. B. Emmons. 1971. The live frog is almost dead. Bioscience 21: 1027-1034.

Gilbert, M., R. Leclair Jr., and R. Fortin. 1994. Reproduction of the northern leopard frog (Rana pipiens) in floodplain habitat in the Richelieu River, P. Quebec, Canada. Journal of Herpetology 28: 465-470.

Gosner, K. L. 1960. A simplified table for staging anuran embryos and larvae with notes on identification. Herpetologica 16: 183-190.

Gromko, M. H., F. S. Mason, and S. J. Smith-Gill. 1973. Analysis of the crowding effect in Rana pipiens tadpoles. Journal of Experimental Zoology 186: 63-72.

Huggins, K., J.-J. Frenette, and M. T. Arts. 2004. Nutritional quality of biofilms with respect to light regime in Lake Saint-Pierre (Québec, Canada). Freshwater Biology 49: 945-959.

John, K. R., and D. Fenster. 1975. The effects of partitions on the growth rates of crowded Rana pipiens tadpoles. American Naturalist 93: 123-130.
Johnson, L. M. 1991. Growth and development of larval northern cricket frogs (Acris crepitans) in relation to phytoplankton abundance. Freshwater Biology 25: 51-59.

Hudon, C. 1997. Impact of water level fluctuations on St. Lawrence River aquatic vegetation. Canadian Journal of Fisheries and Aquatic Sciences 54: 2853-2865.

Kupferberg, S. 1997. The role of larval diet in anuran metamorphosis. Amercian Zoologist. 37: 146-158.

Locky, D. A., J. C. Davies, and B. G. Warner. 2005. Effects of wetland creation on breeding season bird use in boreal eastern Ontario. Canadian Field-Naturalist 119: 64-75.

McDiarmid, R. W., and R. Altig. 1999. Research: Materials and Techniques. Pages 7-24 in Tadpoles, the Biology of Anuran Larvae. Edited by R. W. McDiarmid and R. Altig. University of Chicago Press, Chicago, Illinois, USA.

Murray, D. L. 1990. The effects of food and density on growth and metamorphosis in larval wood frogs (Rana sylvatica) from central Labrador. Canadian Journal of Zoology 68: 1221-1228.

Nusch, E. A. 1980. Comparison of different methods for chlorophyll and phaeopigment determination. Archiv für Hydrobiologie-Beiheft Ergebnisse der Limnologie 14: 1436.

Sheffer, M., S. Rinaldi, A. Gragnani, L. R. Mur, and E. H. Nes. 1997. On the dominance of filamentous cyanobacteria in shallow, turbid lakes. Ecology 78: 272-282.

Semlitsch, R. D., D. E. Scott, and J. H. K. Pechmann. 1988. Time and size at metamorphosis related to adult fitness in Ambystoma talpoideum. Ecology 69: 184-192.

Smith, D. C. 1983. Factors controlling tadpole populations of the chorus frog (Pseudacris triseriata) on Isle Royale, Michigan. Ecology 64: 501-510.

Smith, D. C. 1987. Adult recruitment in chorus frogs: effects of size and date at metamorphosis. Ecology 68: 344-350.

Smith, V. H. 1986. Light and nutrient effects on the relative biomass of blue-green algae in lake phytoplankton. Canadian Journal of Fisheries and Aquatic Sciences 43: 148-153.

Steinwascher, K. 1978. The effect of coprophagy on the growth of Rana catesbeiana tadpoles. Copeia 1978: 130134.

Tardif, D., H. Glémet, P. Brodeur, and M. Mingelbier. 2005. RNA/DNA ratio and total length of yellow perch (Perca flavescens) in managed and natural wetlands of a large fluvial lake. Canadian Journal of Fisheries and Aquatic Sciences. 62: 2211-2218.

Vanrees-Siewert, K. L., and J. J. Dinsmore. 1996. Influence of wetland age on bird use of restored wetlands in Iowa. Wetlands 16: 577-582.

Wassersug, R. J. 1976. The identification of leopard frog tadpoles. Copeia 2: 413-414.

Wetzel, R. G., and G. E. Likens. 1991. Limnological Analyses, second edition. Springer-Verlag. New York, New York, USA.

Wilbur, H. M. 1977. Density-dependent aspects of growth and metamorphosis in Bufo americanus. Ecology 58: 196200.

Wilbur, H. M. 1977b. Interactions of food level and population density in Rana sylvatica. Ecology 58: 206-209.

Wilbur, H. M., and J. P. Collins. 1973. Ecological aspects of amphibian metamorphosis. Science 182: 1305: 1314.

Received 12 February 2010

Accepted 23 July 2010 